\title{
Etos Kerja Guru MI Bersertifikat Profesional
}

\author{
Choirun Nisaa"*, Edi Rispurwanto \\ STIKIP Catur Sakti Yogyakarta \\ *Email korespondensi: choirunn408@gmail.com
}

\begin{abstract}
Abstrak
Undang-undang No.14 Tahun 2005 tentang Guru dan Dosen menyatakan bahwa setiap guru wajib memiliki empat kompetensi dasar, yaitu kompetensi pedagogik, kompetensi kepribadian, kompetensi profesional, dan kompetensi sosial. Tujuan Penelitian untuk mengetahui hubungan antara etos kerja guru dengan sertifikat profesional. Metode penelitian ini yaitu dengan pendekatan diskripstifkualitatif terkait etos kerja kemudian dicari korelasinya dengan sertifikat profesional melalui metode kuantitatif. Subjek penelitian ini ialah guru Madrasah Ibtidaiyah (MI) di Kecamatan Pundong Kabupaten Bantul Yogyakarta berjumlah 16 orang. Hasil penelitian menunjukkan bahwa guru yang bersertifikat pendidik profesional memiliki kompetensi yang baik dan etos kerja tinggi. Berdasarkan hasil analisis korelasi product moment diperoleh koefisien korelasi (rxy) sebesar 0,087 dengan $p=0,750$ yang artinya antara etos kerja guru dengan sertifikat pendidik profesional memang terdapat hubungan, akan tetapi korelasi itu sangat lemah atau sangat rendah.
\end{abstract}

Kata Kunci: Etos Kerja Guru, Guru Profesional, Sertifikat Pendidik

\begin{abstract}
Law Number 14 of 2005 concerning Teachers and Lecturers states that every teacher is required to have four basic competencies, namely pedagogical competence, personality competence, professional competence, and social competence. The research objective was to determine the relationship between teacher work ethics and professional certificates. The method of this research is a qualitative descriptive approach related to work ethic and then the correlation is sought with professional certificates through quantitative methods. The subjects of this study were 16 teachers of Madrasah Ibtidaiyah (MI) in Pundong District, Bantul Regency, Yogyakarta. The results showed that teachers who were certified professional educators had good competence and high work ethic. Based on the results of the product moment correlation analysis, it was obtained a correlation coefficient (rxy) of 0.087 with $p=0.750$, which means that there is a relationship between teacher work ethics and professional educator certificates, but the correlation is very weak or very low.
\end{abstract}

Keywords: Teacher Work Ethic, Professional Teacher, Teacher Certificate 


\section{A. Pendahuluan}

Pendidikan adalah usaha yang dilakukan untuk mengembangkan potensi peserta didik melalui kegiatan pembelajaran. Proses pendidikan dapat berjalan dengan baik jika komponen yang ada dalam sekolah dapat bekerja semaksimal mungkin. Salah satu komponen penunjang keberhasilan pendidikan yaitu guru. Guru harus dapat menjalankan peran utamanya sebagai pendidik, pengajar, administrator, pribadi, dan psikologis. Guru profesional dituntut memiliki tanggung jawab intelektual, profesi, sosial, moral, spiritual, dan tanggung jawab pribadi (Darmadi, 2015).

Peran guru yang begitu besar tidak hanya sebatas menyampaikan pendidikan dalam ranah kognitif atau mentransfer ilmu pengetahuan saja, namun pembentukan kepribadian peserta didik yang menyangkut aspek sikap maupun keterampilan. Sejalan dengan (Mulyasa, 2013) bahwa guru dituntut untuk memahami karakter peserta didik dan melakonkan pembelajaran yang mendidik dan menyenangkan. Maka guru layak juga disebut sebagai manajer sesungguhnya di sekolah (Heriyansyah, 2018) karena peran dan fungsinya yang begitu kompleks.

Undang-undang No.14 Tahun 2005 tentang Guru dan Dosen, menyatakan bahwa setiap guru wajib memiliki empat kompetensi dasar, yaitu: kompetensi pedagogik, kompetensi kepribadian, kompetensi profesional dan kompetensi sosial. Untuk menjadi tenaga profesional, guru perlu dilatih melalui kegiatan pembinaan secara terus menerus dan berkesinambungan untuk meningkatkan kualitas kompetensinya.

Pekerjaan sebagai guru tidak bisa dilakukan oleh sembarang orang tanpa memiliki keahlian khusus. Orang pandai berbicara sekalipun belum dapat disebut sebagai guru. Untuk menjadi seorang guru diperlukan syarat-syarat khusus, apalagi sebagai guru profesional yang harus menguasai betul seluk beluk pendidikan dan pengajaran dengan berbagai ilmu pengetahuan lainnya yang perlu dibina dan dikembangkan melalui pendidikan dan pelatihan yang berkesinambungan.

Guru sebagai tenaga profesional merupakan sarana realisasi tekad pemerintah dalam upaya peningkatan mutu pendidikan di Indonesia. Program 
pengembangan profesionalisme guru secara berkelanjutan memiliki tujuan memelihara, meningkatkan, dan mengembangkan kompetensi guru secara berkelanjutan untuk mencapai standar profesi guru yang dipersyaratkan agar sejalan dengan kemajuan ilmu pengetahuan, tekhnologi dan seni. Profesionalisme guru dalam mendidik ditentukan oleh etos kerja yang berkontribusi signifikan terhadap kinerja guru (Segantara et al., 2017) (Wiratama et al., 2013).

Etos kerja guru merupakan variabel yang perlu mendapatkan perhatian khusus. Berbicara mengenai sebuah lembaga pendidikan maka di dalamnya harus terdapat kurikulum yang paradigmatik, guru yang amanah dan memiliki kompetensi di bidangnya, proses belajar mengajar, lingkungan dan budaya sekolah. Selain itu, terdapat ruang interaksi dan sinergi dengan keluarga dan masyarakat. Etos kerja mengajar sangat penting untuk diperhatikan oleh guru, sebab etos kerja yang baik akan berpengaruh pada mutu dan kualitas pembelajaran, oleh karena itu peningkatan etos kerja dalam mengajar perlu dilakukan oleh semua guru.

Sehubungan dengan sertifikasi guru yang merupakan program dari pemerintah untuk meningkatkan profesionalisme guru dan meningkatkan taraf hidup guru. Tetapi apakah guru yang memiliki sertifikat profesional sudah benarbenar profesional? ataukah hanya memiliki sertifikat profesional tetapi dalam praktiknya tidak mencerminkan perilaku profesional? Pertanyaan ini yang akan dijawab dalam penelitian ini yakni tentang etos kerja guru dengan sertifikat pendidik profesional.

Sertifikasi guru dapat dikatakan proses pemberian sertifikasi pendidik kepada guru yang telah memenuhi persyaratan tertentu yaitu kualifikasi akademik, kompetensi, sehat jasmani dan rohani, serta memiliki kemampuan untuk mewujudkan tujuan pendidikan Nasional yang dibarengi dengan peningkatan kesejahteraan yang layak. Guru merupakan jabatan atau profesi yang memerlukan keahlian khusus sebagai guru sekaligus panggilan jiwa yang harus memiliki etos kerja tinggi.

Guru pada jenjang pendidikan dasar Islam atau Madrasah Ibtidaiyah (MI) selain dituntut profesional, beretos kerja tinggi, harus pula memahami anak didik 
dengan baik. Masa anak-anak adalah masa membangun pondasi karakter yang akan menentukan untuk masa depan anak. Guru MI di Kecamatan Pundong Bantul Yogyakarta telah memiliki sertifikat pendidik profesional. Maka menggali bagaimana hubungan sertifikat pendidik profesional dengan etos kerja menjadi kajian yang menarik.

\section{B. Metode Penelitian}

Jenis penelitian ini termasuk penelitian campuran antara kualitatif dengan kuantitatif. Metode kualitatif dengan pendekatan deskriptif digunakan untuk menjabarkan etos kerja guru. Sementara metode kuantitatif dipakai untuk mendapatkan data korelasi antara etos kerja guru dengan sertifikat pendidik profesional. Teknik pengambilan data menggunakan observasi, wawancara, dokumentasi, dan angket. Analisis interaktif (Miles et al., 2014) digunakan untuk mendiskripsikan etos kerja guru meliputi pengumpulan data, reduksi data, penyajian data, dan penarikan kesimpulan. Selanjutnya dilakukan analisis kuantitatif dengan product momen untuk mengetahui korelasi antara etos kerja dengan sertifikat pendidik profesional. Subjek dalam penelitian ini ialah guru MI di kecamatan Pundong kabupaten Bantul DIY berjumlah 16 orang yang telah memperoleh sertifikat pendidik profesional.

\section{Hasil dan Pembahasan}

\section{Etos Kerja Guru MI Bersertifikat Pendidik Profesional}

Menilai etos kerja guru MI di Kecamatan Pundong Bantul Yogyakarta diawali dengan melihat kompetensinya. Guru profesional diharuskan memiliki empat kompetensi utama yaitu kompetensi pedagogik, profesioan, sosial, dan personal. Hasil penelitian terkait kompetensi guru profesional menunjukkan data berikut:

Tabel 1. Kompetensi Profesional Guru

\begin{tabular}{|c|c|c|c|c|}
\hline NO & Kompetensi & Minimal & Mean ( $\bar{x})$ & Maxsimal \\
\hline 1 & Pedagogik & 1,50 & 1,91 & 2,50 \\
\hline 2 & Sosial & 4,00 & 4,00 & 4,00 \\
\hline 3 & Profesional & 3,90 & 3,93 & 3,97 \\
\hline 4 & Kepribadian & 3,80 & 3,89 & 4,00 \\
\hline & Mean ( $\bar{x})$ & 3,31 & 3,43 & 3,58 \\
\hline
\end{tabular}


Pada tabel di atas skor kompetensi Pedagogik minimal $(1,50)$, rerata $(1,91)$, dan skor maksimal $(2,50)$. Ini berarti bahwa dalam pemahaman seorang guru tentang kompetensi pedagogik masih sangat rendah. Kompetensi pedagogik adalah kemampuan mengelola pembelajaran peserta didik yang meliputi pemahaman terhadap peserta didik, perancangan dan pelaksanaan pembelajaran, evaluasi hasil belajar, dan pengembangan peserta didik untuk mengaktualisasikan berbagai potensi yang dimilikinya.

Kompetensi pedagogik sangatlah penting dimiliki oleh seorang guru dalam mengelola pembelajaran peserta didik. Dari hasil wawancara dengan guru menyatakan bahwa rendahnya kompetensi pedagogik disebabkan karena kurangnya pemahaman guru dalam rancangan RPP (Rencana Pelaksanaan Pembelajaran) yang berkaitan dengan administrasi kelas seperti silabus, rpp, prota, promes, dll. Selain itu guru merasa kesulitan dalam mengembangkan potensi peserta didik, sebab potensi dari setiap individu berbeda dan dari latar belakang keluarga yang berbeda pula.

Skor pada kompetensi Sosial dapat dicermati bahwa skor minimal $(4,00)$, rerata $(4,00)$, skor maksimal $(4,00)$ ini berarti bahwa sejumlah 16 guru sudah mampu mengimplemantasikan kompetensi Sosial sebagai salah satu ciri guru profesional. Komnpetensi sosial adalah kemampuan guru sebagai bagian dari masyarakat untuk berkomunikasi dan bergaul secara efektif dengan peserta didik, sesama pendidik, tenaga kependidikan, orang tua/wali peserta didik, dan masyarakat sekitar.

Kompetensi Sosial sangatlah perlu dimiliki oleh seorang pendidik. Guru adalah makhluk sosial yang dalam kehidupannya tidak bisa lepas dari kehidupan sosial masyarakat dan lingkungannya, oleh karena itu guru dituntut untuk memiliki kompetensi sosial yang memadai, terutama dalam kaitannya dengan pendidikan, yang tidak terbatas pada pembelajaran di sekolah tetapi juga pada pendidikan yang terjadi dan berlangsung di masyarakat.

Berkaitan dengan tanggung jawab guru harus mengetahui serta memahami nilai, norma moral dan sosial serta berusaha berperilaku dan berbuat sesuai dengan nilai dan norma. Guru juga harus bertanggung jawab 
terhadap segala tindakannya dalam pembelajaran di sekolah, dan dalam kehidupan bermasyarakat. Berkenaan dengan wibawa guru harus memiliki kelebihan dalam merealisasikan nilai spiritual, emosional, moral, sosial dan intelektual dalam pribadinya serta memiliki kelebihan dalam pemahaman IPTEK dan seni sesuai mata pelajaran yang diampunya. Guru juga harus mampu bertindak dan mengambil keputusan secara cepat, tepat waktu dan tepat sasaran terutama berkaitan dengan masalah pembelajaran dan peserta didik tidak menunggu perintah atasan atau kepala sekolah.

Dalam penanaman disiplin guru harus memulai dari dirinya sendiri, dalam berbagai tindakan dan perilakunya. Di sinilah pentingnya kompetensi personal atau pribadi guru. Sebagai individu yang berkecimpung dalam pendidikan, guru harus memiliki kepribadian yang mencerminkan seorang pendidik. Tuntutanakan akan kepribadian seorang guru dirasa lebih berat dari profesi lainnya. Ungkapan yang sering dikemukakan adalah bahwa "guru bisa digugu dan ditiru". Dari penelitian ini sejumlah guru yang bersertifikat profesional telah mampu mengimplementasikan kompetensi sosial dalam kehidupannya sebagai guru.

Skor kompetensi profesional yakni skor minimal $(3,90)$, rerata $(3,93)$, skor maksimal $(3,97)$. Memahami dari hasil penelitian tersebut nampak bahwa kompetensi profesional merupakan kompetensi yang harus dikuasai guru dalam kaitannya dengan pelaksanaan utamanya mengajar. Kompetensi Profesional adalah kemampuan penguasaan materi pembelajaran secara luas dan mendalam yang memungkinkan membimbing peserta didik memenuhi standart kompetensi yang ditetapkan dalam Standar Nasional Pendidikan.

Sehubungan dengan hal tersebut di atas, bahwa kompetensi Profesional yang dimiliki oleh guru profesional meliputi: menguasai keunikan peserta didik, kurikulum, intruksional, media pembelajaran dan evaluasi. Penting bagi setiap guru apalagi yang sudah profesional dalam mengelola atau menguasai anak, karena setiap anak memiliki kompetensi dan keunikan yang berbeda-beda, dengan mengerti anak didiknya seorang guru dapat dengan mudah memberikan ilmu bahkan mengarahkan anak didiknya sesuai kompetensi yang dimiliki oleh anak didiknya tersebut. 
Guru yang dapat menguasai anak didiknya secara moril akan membuat anak lebih mudah mencerna pelajaran yang disampaikan oleh guru. Untuk itu setiap guru harus dapat menguasai anak didiknya karena dengan memahami guru akan mengetahui apa, dan bagimana anak didiknya. Selain itu juga akan memudahkan guru untuk mengembangkan kreatifitas kognitif anak jika seorang guru dapat menguasai anak didiknya dengan baik.

Dalam dunia pendidikan kurikulum merupakan komponen pokok yang harus ada karena merupakan program dan aktivitas utama di dalam pendidikan. Kurikulum tidak hanya meliputi bahan pelajaran, tetapi juga meliputi seluruh kehidupan dalam kelas, termasuk di dalamnya hubungan sosial antara guru dan murid, metode mengajar dan cara mengevaluasi. Jadi kurikulum sangatlah penting untuk diketahui oleh guru profesional sebagai acuan dalam melaksanakan pembelajaran bagi anak didiknya untuk mencapai tujuan dari pembelajaran.

Siswa mempunyai kebiasaan yang berbeda-beda dan karakteristik yang berbeda-beda pula. Dari perbedaan tersebut guru harus mempunyai beberapa metode pembelajaran yang cocok bagi siswanya, agar siswa tidak jenuh dan ada variasi dalam pembelajaran. Salah satunya dengan menyiapkan media pembelajaran yang merupakan suatu lantaran atau alat untuk memahamkan siswa. Dengan adanya media pembelajaran guru akan terbantu dalam memahamkan siswanya, siswa juga akan mudah terbantu dengan adanya media yang sesuai dengan karakteristik materi dan anak.

Setiap pembelajaran harus ada evaluasi pembelajaran, hal ini bertujuan untuk mengukur pemahaman siswa terhadap pembelajaran yang disampaikan oleh guru. Dari hasil evaluasi tersebut guru yang profesional harus mempu mengevaluasi lagi hasil dari evaluasi untuk meningkatkan hasil yang lebih memuaskan lagi dan untuk memperbaiki untuk kegiatan pembelajaran dan evaluasi berikutnya yang lebih baik lagi. Guru MI profesional sudah menyiapkan instrumen evaluasi, melaksanakan evaluasi proses dan hasil, memaknai hasil evaluasi, menindak lanjuti hasil evaluasi, dan memanfaatkan hasil penilaian pembelajaran untuk perbaikan kualitas. 
Pada tabel kompetensi kepribadian dapat dicermati bahwa skor minimal $(3,80)$, rerata $(3,89)$, skor maksimal $(4,00)$ dari hasil penelitian tersebut dapat dikatakan bahwa kompetensi kepribadian menunjukkan kategori tinggi, ini artinya bahwa kompetensi kepribadian sangat besar pengaruhnya terhadap pertumbuhan dan perkembangan pribadi para peserta didik.

Kompetensi kepribadian adalah kemampuan kepribadian yang mantap, stabil, dewasa, arif dan berwibawa, menjadi teladan bagi peserta didik, dan berakhlak mulia.Kompetensi kepribadian memiliki peran dan fungsi yang sangat penting dalam pembentukan kepribadian anak guna menyiapkan dan mengembangkan sumber daya manusia (SDM), serta mensejahterakan masyarakat, kemajuan negara, dan bangsa.

Setiap guru dituntut untuk memiliki kompetensi kepribadian yang memadai, bahkan kompetensi ini akan melandasi atau menjadi landasan bagi kompetensi yang lain. Guru tidak hanya dituntut untuk mampu memaknai pembelajaran, tetapi yang paling penting adalah bagaimana menjadikan pembelajaran ajang pembentukan kompetensi dan perbaikan kualitas pribadi peserta didik. Agar dapat melaksanakan tugasnya dengan baik, profesional dan dapat dipertanggung jawabkan guru harus memiliki kepribadian yang mantap, stabil, dan dewasa.

Penting bagi setiap memiliki kompetensi kepribadian karena banyak masalah pendidikan yang disebabkan oleh faktor kepribadian guru yang kurang mantap, kurang stabil, dan kurang dewasa. Selain itu seorang guru juga harus belajar untuk disiplin dan seorang guru harus memulainya seorang guru harus memiliki pribadi yang disiplin arif dan berwibawa. Tidak hanya itu seorang guru harus berakhlak mulia karena seorang guru adalah penasehat bagi peserta didik. Sehingga harapannya akan menjadi penerus bangsa yang berakhlakhul karimah.

Sebagai garda depan dalam pelaksanaan proses pembelajaran, guru menjadi sorotan masyarakat terkait dengan etos kerjanya, yaitu totalitas, dedikasi, dan loyalitas pengabdian. Etos kerja guru akan berdampak kepada pendidikan bermutu. Selain itu etos kerja guru juga sangat ditentukan oleh output dari lembaga pendidikan tenaga Kependidikan (LPTK). Sebagai 
instuasi penghasil tenaga guru, LPTK bertanggung jawab menciptakan guru berkualitas, berwawasan serta mampu membentuk sumber daya manusia mandiri, cerdas, bertanggung jawab dan berkepribadian. Tentunya suatu ketika berdampak kepada pembentukan sumber daya manusia berkualitas pula.

Etos kerja terbentuk bilamana masing-masing struktur memiliki tanggung jawab dan memahami akan tugas dan kewajiban masing-masing. Ukuran etos kerja guru terlihat dari rasa tanggung jawabnya menjalankan amanah, profesi yang diembannya, rasa tanggung jawab moral dipundaknya. Semua itu akan terlihat kepada kepatuhan dan loyalitasnya di dalam menjalankan tugas keguruannya di dalam kelas dan tugas kependidikannya di luar kelas. Sikap ini akan dibarengi pula dengan rasa tanggung jawabnya mempersiapkan segala perlengkapan pengajaran sebelum melaksanakan proses pembelajaran. Selain itu, guru juga sudah mempertimbangkan akan metodologi yang akan digunakan, termasuk alat media pendidikan yang akan dipakai, serta alat penilaian apa yang digunakan di dalam pelaksanaan evaluasi. Etos kerja guru dari hari kehari, minggu ke minggu dan tahun ke tahun terus ditingkatkan.

Etos kerja guru akan menjadi optimal, bilamana diintegrasikan dengan komponen yang ada di sekolah, apakah itu kepala sekolah, guru, karyawan maupun anak didik. Etos kerja guru akan bermakna bila dibarengi dengan niat yang bersih dan ikhlas, serta selalu menyadari akan kekurangan yang ada pada dirinya, dan berupaya untuk dapat meningkatkan atas kekurangan tersebut sebagai upaya untuk meningkatkan kearah yang lebih baik.

Tabel 2. Angket Etos Kerja

\begin{tabular}{|c|c|c|c|c|}
\hline No & \multicolumn{1}{|c|}{ Indikator } & Minimal & Mean & Maksimal \\
\hline 1 & Etos kerja & 3,25 & 3,32 & 3,40 \\
\hline
\end{tabular}

Dari tabel di atas dapat dicermati bahwa Etos Kerja skor minimal $(3,25)$, rerata $(3,32)$, skor maksimal $(3,40)$. Ini berarti bahwa kinerja atau etos kerja dari guru yang bersertifikat profesional di kecamatan pundong sudah menunjukkan etos kerja yang tinggi yang bisa melakukan pekerjaannya dengan cara yang tepat, melakukan pekerjaannya dengan waktu yang tepat, 
melakukan pekerjaan dengan tepat tujuan, melakukan pekerjaan dengan selalu memasang target, melakukan pekerjaan sesuai waktunya, melakukan pekerjaan tepat capaian, dan melakukan pekerjaan dengan tuntas sebagai seorang guru yang profesional.

Etos kerja adalah suatu pandangan dan sikap suatu bangsa atau satu umat terhadap kerja. Kalau pandangan dan sikap itu, melihat kerja sebagai suatu hal yang luhur untuk eksistensi manusia, maka etos kerja itu akan tinggi. Sebaliknya kalau melihat kerja sebagai suatu hal tak berarti untuk kehidupan manusia, apalagi kalau sama sekali tidak ada pandangan dan sikap terhadap kerja maka etos kerja itu dengan sendirinya rendah.

Usaha membangun etos kerja guru (Syarifuddin, 2019) adalah terpeliharanya rasa mendapatkan perlakuan yang fair: jujur, sehat, adil dsb serta terpeliharanya rasa mencapai. Mereka ingin merasa mampu mengerjakan tugas-tugasnya, menghendaki untuk merasakan bahwa mereka membuat suatu sumbangan yang nyata bagi masyarakat melalui pekerjaannya, merasa maju dalam pendidikannya dan menghendaki adanya rasa tumbuh dan mengembangkan karir dalam pekerjaannya.

Diharapkan dengan memiliki etos kerja yang tinggi seorang guru yang bersertifikat profesional akan baik pula dalam melakukan tugas-tugasnya sebagai seorang pendidik bagi anak didiknya. Etos kerja guru dapat berarti ciri-ciri atau sifat (karakteristik) mengenai cara bekerja, yang sekaligus mengandung makna kualitas esensialnya, sikap dan kebiasaannya serta pandangannya terhadap kerja yang dimiliki oleh seorang guru dalam melaksanakan dan mengembangkan kegiatan pendidikan disekolah. Seorang guru dikatakan mempunyai etos/ semangat kerja yang baik apabila dia melaksanakan tugas-tugasnya dengan penuh tanggung jawab, baik tugas pokok profesi ataupun tugas yang berkaitan dengan keprofesional.

\section{Korelasi Guru Bersertifikat Profesional dengan Etos Kerja}

Etos kerja adalah ciri-ciri atau sifat (karakteristik) mengenai cara bekerja, yang sekaligus mengandung makna kualitas esensialnya, sikap dan kebiasaannya serta pandangannya terhadap kerja yang dimiliki oleh seorang guru dalam melaksanakan dan mengembangkan kegiatan pendidikan di 
sekolah. Variabel penilaian terhadap etos kerja guru profesional guru diukur dengan menggunakan angket secara silang. Penilaian yang dimaksud dalam penelitian ini adalah suatu tindakan atau langkah untuk menentukan mutu atau kualitas sesuatu. Dalam hal ini penelitian dilakukan kepada 16 guru yang bersertifikat di kecamatan Pundong.

Setelah diketahui keadaan pengembangan etos kerja guru dan profesional guru, kemudian akan dilakukan uji hipotessis. Uji Hipotesis merupakan jawaban sementara atas masalah yang dirumuskan. Oleh karena itu jawaban sementara ini harus diuji kebenarannya secara empiris. Apakah ada yang terkumpul mendukung hipotesis yang diajukan atau justru sebaliknya yaitu menolak hipotesis yang diajukan. Adapun hipotesis yang diajukan adalah Ha: terdapat korelasi positif yang signifikan antara etos kerja guru dengan sertifikat pendidik profesional di kecamatan Pundong; Ho: tidak ada korelasi positif yang signifikan antara etos kerja guru dengan sertifikat pendidik profesional di kecamatan Pundong.

Dalam memberikan intrepretasi terhadap nilai koefisien korelasi dapat didasarkan pada tabel:

Tabel 3. Intepretasi Korelasi

\begin{tabular}{|c|l|}
\hline Besarnya 'r' & \multicolumn{1}{|c|}{ Intepretasi } \\
\hline $0,00-0,20$ & $\begin{array}{l}\text { Antara variabel X dan variabel Y memang terdapat } \\
\text { korelasi, akan tetapi korelasi itu sangat lemah atau } \\
\text { sangat rendah, sehingga korelasi itu diabaikan } \\
\text { (dianggap tidak ada korelasi variabel X dan variabel Y) }\end{array}$ \\
\hline $0,20-0,40$ & $\begin{array}{l}\text { Antara variabel X dan variabel Y memang terdapat } \\
\text { korelasi yang lemah atau rendah }\end{array}$ \\
\hline $0,40-0,70$ & $\begin{array}{l}\text { Antara variabel X dan variabel Y memang terdapat } \\
\text { korelasi yang sedang atau cukupan }\end{array}$ \\
\hline $0,90-1,00$ & $\begin{array}{l}\text { Antara variabel X dan variabel Y memang terdapat } \\
\text { korelasi yang sangat kuat atau sangat tinggi (Anas } \\
\text { Sudjiono:2001). }\end{array}$ \\
\hline
\end{tabular}

Berdasarkan hasil analisis korelasi product moment diperoleh koefisien korelasi (rxy) sebesar 0,087 dengan $p=0,750$. Menurut kategori koefisien di atas, nilai koefisien yang menunjukkan hubungan antara etos kerja guru dengan profesional guru masuk pada kategori yang pertama yaitu $0,00-0,20$ yang artinya bahwa memang terdapat korelasi, akan tetapi korelasi itu sangat 
lemah atau sangat rendah sehingga korelasi itu rendah atau diangap tidak ada korelasi antara etos kerja guru dengan profesional guru.

Dari hasil diatas menunjukkan bahwa antara etos kerja guru dengan professional guru terdapat hubungan akan tetapi tidak ada korelasi yang signifikan antara etos kerja guru bersertifikat dengan profesional guru di kecamatan Pundong. Dengan demikian Ho diterima dan Ha ditolak,

Peran kepala sekolah dalam meningkatkan etos kerja guru profesional sangat penting. (Syukri et al., 2019) mengemukakan bahwa kepala sekolah harus memiliki peran aktif dalam upaya meningkatkan etos kerja guru yaitu dengan menjalin hubungan yang harmonis terhadap sesama pengajar (para guru), memberikan kesejahteraan kepada para guru yang memadai, mengontrol dan mengevaluasi guru dalam menjalankan tugas mereka sehingga dapat merubah pola pikir dalam membangun karakter guru, sehingga para guru turut membangun sekolah menjadi terdepan/ berprestasi sesuai visi dan misinya.

Lebih jauh (Wahyuningsih, 2016) menjelaskan bahwa untuk mencapai tujuan yang telah dirumuskan oleh suatu organisasi dibutuhkan pandangan yang positif tentang kerja. Pandangan dan sikap yang positif akan membentuk etos kerja yang baik. Etos kerja merupakan cara individu memberikan ekspresi terhadap kerja dapat menjadi pendorong atau penggerak untuk meraih keberhasilan. Kekuatan pendorong atau penggerak dapat menciptakan seseorang untuk siap dalam bekerja bahkan bekerja keras dari aktivitas bekerja.

Kecanggihan teknologi pada abad 21 berbeda dengan abad sebelumnya tentu menjadi problem bagi para guru yang tidak ada keinginan untuk mengikuti perubahan. Pada abad ini perkembangan ilmu pengetahuan biasa disegala bidang, terutama bidang Information and Communication Technology (ICT). Secara konseptual guru sebagai tenaga profesional harus memenuhi berbagai persyaratan untuk menjalankan tugas dan kewenangan secara profesional, sementara kondisi riil di lapangan masih sangat memprihatinkan, baik secara kuantitas maupun kualitas maupun profesionalitas guru (Lince, 2016). 
Guru di era konvensional kesulitan untuk membangunkomunikasi yang efektif dengan siswa dari era digital. Maka pengembangan profesi guru harus dilaksanakan secara berkesinambungan, dimaksudkan untuk dapat merangsang, memelihara, dan meningkatkan kompetensi guru dalam memecahkan masalah pendidikan dan pembelajaran yang berdampak pada peningkatan mutu, dan peningkatan kompetensi guru dalam melaksanakan tugas dan tanggung jawab secara profesional. Jika hal ini dilakukan maka guru yang bersertifikat profesional tidak hanya memiliki sertifikat profesional akan tetapi juga memiliki etos kerja yang memenuhi syarat.

\section{Kesimpulan}

Berdasarkan data penelitian dan analisis yang dilakukan dapat disimpulkan bahwa guru MI di Kecamatan Pundong Bantul Yogyakarta memiliki etos kerja yang tinggi. Akan tetapi kompetensi pedagogiknya masih rendah dibandingkan dengan kompetensi profesional, sosial, dan personal. Hasil uji analisis korelasi product moment diperoleh koefisien korelasi (rxy) sebesar 0,087 dengan $\mathrm{p}=0,750$ menunjukkan adanya hubungan antara etos kerja guru dengan sertifikat pendidik profesional akan tetapi korelasi itu sangat lemah atau sangat rendah.

\section{Daftar Pustaka}

Asy'arie, M. (1997). Islam Etos Kerja dan Pemberdayaan Ekonomi Umat. (Yogyakarta: Lesfi)

Darmadi, H. (2015). Tugas, Peran, Kompetensi, dan Tanggung Jawab menjadi Guru Profesional. Jurnal Edukasia, https://doi.org/http://dx.doi.org/10.31571/edukasi.v13i2.113

Heriyansyah, H. (2018). Guru adalah Manajer Sesungguhnya di Sekolah. Islamic Management: Jurnal Manajemen Pendidikan Islam, 1(1). https://doi.org/10.30868/im.v1i01.218

Lince, R. (2016). Strategi Peningkatan Profesionalisme Guru Dalam Menghadapi Tantangan Di Era Digital. Prosiding Temu Ilmiah Nasional Guru (Ting).

Miles, M. B., Huberman, A. M., \& Saldana, J. (2014). Cross-case data analysis. In Qualitative data analysis: An expanded sourcebook.

Mulyasa. (2013). Pengembangan dan Implementasi Kurikulum 2013. In Bandung: 
Remaja Rosdakarya. Remaja Rosdakarya.

Segantara, I. G. M., Yudana, I. M., \& Sunu, I. G. K. A. (2017). Studi Korelasi antara Motivasi Kerja, Kompetensi Profesional Guru, dan Etos Kerja terhadap Kinerja Guru. Jurnal Penelitian Dan Pengembangan Sains Dan Humaniora, 1(1), 29-34. https://doi.org/10.23887/jppsh.v1i1.12927

Syarifuddin, S. (2019). Membangun Etos Kerja Guru. Al Amin: Jurnal Kajian Ilmu Dan Budaya Islam, 1(2). https://doi.org/10.36670/alamin.v1i2.10

Syukri, A., Nuzuar, N., \& Warsah, I. (2019). Peran Kepala Madrasah dalam Meningkatkan Etos Kerja Guru. Journal of Administration and Educational Management (Alignment), 2(1). https://doi.org/10.31539/alignment.v2i1.725

Wahyuningsih, N. (2016). Membangun Sikap dan Etos Kerja. Al-Amwal: Jurnal Kajian Ekonomi Dan Perbankan Syariah, 8(2). https://doi.org/http://dx.doi.org/10.24235/amwal.v8i2.484

Wiratama, A., Yudana, I. M., \& Candiasa. (2013). Kontribusi Sikap Profesional, Etos Kerja dan Iklim Kerja terhadap Kinerja Guru SMP Negeri di Kecamatan Tampaksiring. Journal Program Pascasarjana Universitas Pendidikan Ganesha, 4(1). 